\title{
Team Diversity on Team Effectiveness: the case of the Construction industry in the Ashanti Region
}

\author{
Maura Boansi Amoakohene (Mrs.) \\ Kumasi Technical University, Kumasi, Ghana (Vice-Chancellor's Secretariat-Registry) \\ mauraamoakohene@gmail.com \\ https://orcid.org/0000-0002-0741-8229
}

\author{
Isaac Bonituo Paruzie \\ Bia College of Health and Skills Development, Sefwi Debiso, Ghana \\ paboni71@gmail.com \\ https://orcid.org/0000-0001-6466-4779
}

\section{Florence Ellis}

Kwame Nkrumah University of Science and Technology Department of Human

Resource and Organizational Development, Kumasi, Ghana

florenceyaellis@yahoo.co.uk

https://orcid.org/0000-0002-4349-2733

\begin{abstract}
Diverse workgroups and team management are some of the most challenging and pressing challenges organizations face in these modern times (TsuiandGutek, 1999). Companies, however, recognize the need to leverage the diversity of their employees to sustain competitive advantages in a global workplace (Offerman and Gowing, 1990; Thomas and Ely, 1996; Yaprak, 2002). Studies have generally shown that diverse teams mostly perform better, but diversity in teams can negatively affect team effectiveness. This study explored the effect of team diversity on team effectiveness. The study reviewed the literature on the concepts of diversity and team effectiveness. Data were collected via questionnaire and semistructured interviews from one hundred and sixty-four (164) professionals from the construction industry. The mixed methodology was used to collect and analyze the data. The study findings revealed that the construction industry recognizes team diversity a valid contribution to ensuring team effectiveness. Also, diversity in gender, tribe, and religion does not affect team output and the final project negatively but instead improves cohesiveness or collaboration among team members. The study recommended that there should be a well-defined conflict management policy in the construction industry that will help track grievances to resolve them early.
\end{abstract}

Keywords: Diversity, Team effectiveness, diversity conflict 


\section{Introduction}

The contribution of the construction industry to the economy of Ghana cannot be overemphasized (Tuuli et al., 2007). It was estimated by the World Bank (2003) in 2003 that the annual value of public procurement of goods, work, and services was US\$ 600 million representing about $10 \%$ of Ghana's gross national product (GNP). It was again observed that the bulk of the expenditure programs in Ministries, Department, and Agencies (MDAs) and District Assemblies involve capital construction procurement (World Bank, 2003). For example, the construction industry in the Ashanti region plays a crucial role in the economy of Ghana as so many skilled and unskilled laborers are employed daily. This sector has contributed tremendously to the development of the economy and the livelihood of people within the Ashanti region. However, the construction management within the Ghanaian economy is still very inefficient so these inefficiencies are characterized by delays and poor project implementation (World Bank, 2003). This has negative consequences for project execution and leads to the adverse relationship among project team members like the project managers, architects, surveyors, quantity surveyors, constructors, artisans, and laborers. It is known that managing a diverse workgroup or team is one of the most difficult and pressing challenges in the modern organization. This is because it may lead to team effectiveness (Byrne, 1971; Tajfel and Turner, 1986) and therefore the need to understand team diversity and team effectiveness.

Diversity in a team can make it possible for a company to gain a competitive advantage as they can come out with very creative and innovative ideas for accomplishing goals. The diverse expertise in teams presents an opportunity to examine how this will lead to team performance and subsequently team effectiveness. Construction projects bring on board so many individuals from different backgrounds and with different knowledge, attitude, experience, and perspective to work. There is relatively little published information about the effect of team diversity on team effectiveness on a construction project in a developing country like Ghana. This study will also help the contractor, architect, client, government, consultant, and other stakeholders of the construction project to understand the factors that contribute to help an effective project team. The findings from this study will contribute to balancing the academic viewpoint by examining the team effectiveness and its role in contributing to team performance and its success. The key questions this study poses are: What are the forms of diversity in the construction industry in the Ashanti Region?; Does diversity in teams cause conflict and does conflict in team affect team effectiveness in the construction industry in the Ashanti region?; What are the factors influencing team effectiveness?, and; how does team diversity influences team effectiveness? This study sought to explore the following objectives:

a) To determine the forms of diversity in the construction industry in the Ashanti Region.

b) To determine the influence of team diversity on team conflict in the construction industry in the Ashanti Region.

c) To determine the factors influencing team effectiveness in the Construction industry in the Ashanti Region.

d) To determine whether team diversity has effects on team effectiveness in the Construction Industry in the Ashanti Region.

\section{Literature review}

Team diversity plays a crucial role in determining the effectiveness of team performance in every industry. Some various dimensions and factors come to play in this endeavor and as a result, relevant literature regarding the effect of team diversity on team effectiveness was reviewed. 
Team diversity can be by age, gender, and tribe. Gender diversity and inclusion, for instance, have a major impact on organizational accomplishment and progression. The issue of gender diversity in most organizations is treated with the utmost importance as there has been an upsurge in the recognition of the benefits associated with incorporating gender in team diversity. It has become obvious that encouraging gender diversity and inclusion in organizational team diversity has become a successful principle for boosting creativity, innovation, enthusiasm, and organizational effectiveness (Kaur and Arora, 2020). As a result team diversity management has been recognized as a relevant means for promoting diversity. Team diversity management is greatly influenced by the management of cultural diversity, employees' perception of marginalization, and conflict. How diversity is managed in an industry or organization determines the level of organizational efficiency that would be achieved. Managers handling team diversity are generally encouraged to prioritized diversity management and implement measures to ensure its effective implementation (Inegbedion et al., 2020). According to Tenas (2012), diversity management allows organizations and industry players to belittle the challenges associated with team diversity and rather focus on harnessing the benefits associated with bringing and working with personnel from diverse backgrounds and experiences.

Studies revealed that there is a positive relationship between team diversity and team effectiveness as team building and team training as well as cultural diversity was found to be influential in organizational performance and effectiveness. It was also revealed that a $1 \%$ upsurge in team diversity results in a 3\% to $9 \%$ rise in the profits of organizations (Odita and Egbule, 2015; Bahl, 2018).

According to Urbancova et al. (2020), diversity is a phenomenon that, due to increasing globalization, appears ever more frequently in all areas of human activity and performance, including the labor market and working teams. Due to these changes, the researchers aimed to identify and evaluate the practice of diversity management as a factor of the sustainability of competitive advantage about the examined factors of diversity. The results were obtained with the aid of a questionnaire survey from 549 Czech companies. The study findings indicated that there is a statistical dependence between the application of diversity management and the commercial sector in which the organization operates and the size of the organization. Organizations identified the following as the most significant benefits of the application of diversity management: retention of key employees (43.9\%), improved motivation and performance of existing employees (39.3\%), and enhancement to the realenvironment in the place of work $(33.9 \%)$. The study concluded that the application of diversity management can be a successful tool to gain a competitive advantage in managing the human resources of organizations.

\section{Methods}

The researcher adopted a case study strategy. A case study explores a research topic or phenomenon within its context or several real-life contexts. A case study helps the researcher to gain a rich understanding of the context of the research and the processes being enacted (Eisenhardt and Graebner, 2007). The explorative nature of the research informed the researcher to use the case study strategy and as such used the mixed methods to collect data - thus questionnaire and interview. A cross-sectional survey with a questionnaire and semi-structured interview were used to provide answers to the research questions. The research was crosssectional because it was meant for a particular phenomenon and at a particular time. The research was conducted in different organizations as multiple cases (Yin, 2003) which include Ghanaian professionals such as architects, engineers, surveyors, quantity surveyors, contractors, artisans, 
and laborers. The researcher focused on professionals who worked in teams made of different professionals in the construction industry who had much knowledge in the research area.

The researcher adopted the mixed strategy, thus qualitative and quantitative on the ground that the explore-descriptive nature of the study allowed the researcher to present responses collected from interviews and questionnaires to be processed or analyzed quantitatively instead of relying solely on the qualitative technique of content analysis. The data were analyzed statistically to determine whether the diversity in terms of different employee groups to be compared for differences in gender, religion, age, profession, and tribe had any impact on output.

The researcher employed closed-ended questions to obtain data about the effect of diversity on team effectiveness on construction projects in the Ashanti region, specifically Kumasi metro. Semi-structured interviews were also conducted to elicit information on the effect of team diversity on team output, the relationship between conflict and team effectiveness, and the contribution of project leaders in ensuring team effectiveness.

The population of the study was drawn from employees of construction projects within the Kumasi metro in the Ashanti region. The researcher took into consideration various categories of employees within the construction industry. The sample size of the study was 164 employees which consist of architects, contractors/subcontractors, engineers, and artisans of the construction projects. Questionnaires were given to one hundred and eight professionals whereas fifty-six respondents were also interviewed. The study adopted the purposive and quota sampling techniques due to their abilities in facilitating data collection from the different professionals used in describing and explaining the key themes that were observed.

In analyzing the qualitative data, an initial inductive approach was used. This involved familiarization with data and conceptualization and ordering of data to bring out emerging themes (Easterby-Smith et al., 2008; Miles and Huberman, 1994). The process continued with the adoption of a deductive approach to qualitative data analysis. This involved the development of a "code" which related to "themes and issues in the data identified as important for interpretation" and reflected themes derived from the research conceptual framework and reviewed literature. Then the cut and paste approach was used. This involved continuous regrouping "chucks" of verbatim text. The quantitative data collected were analyzed using the descriptive tool such as the frequency tables generated with the aid of the Statistical Package for Social Scientist (SPSS). The analyses in a form of tables and statistics provided the researcher with a more flexible means of interpreting the data collected. It also made it feasible for the research objectives and research questions to be answered.

For the basis of the decision, the evaluation required some standards in the form of "benchmarking" or criteria. The quality of what was observed within each quality indicator was decided as used by (Gadzekpo, 2007) which were When "Strongly Agree" is chosen it means "very good", which indicates key points with minor or no flaws, "Agree" indicates "good", which reveals that strong point prevail over flaws even though both occur. A response stressing on "Not Sure" indicates the respondent's inability to decide in favor of the strengths or weaknesses of that question being evaluated. The option of "Disagree" specifies that the respondent is referring to "fair" which highlights flaws prevailing over key points even though both occur or exist; but when "Strongly Disagree" is picked; it indicates "bad" indicating major weaknesses with slight or no strengths.

\section{Findings}


A summary of the demographic characteristics of respondents as revealed in Table 4.1 shows that $101(93.5 \%)$ were males while $7(6.5 \%)$ were females. Christians were $88(81.5 \%), 19(17.6 \%)$ were Islam and $1(0.9 \%)$ were of the traditional religion. The educational qualification with the highest distribution was second degree 44(40.7\%), followed by first degree 38(35.2), higher diploma $23(21.3 \%)$, O and A level $3(2.8 \%)$. Sampling was also done to cover all the relevant designation in the construction industry with Engineers 46(42.6\%) commanding the highest distribution, followed by the Surveyor/Quantity Surveyor, 39(36.1\%). The rest in terms of descending order of distribution was Architects 14(13.0\%), Project managers 4(3.7\%), Artisans 3(2.8), and valuers $1(0.9 \%)$.

Table 4.1.Distribution of Respondents in the Study Area

\begin{tabular}{lll}
\hline Gender: & Frequency & Percent \\
\hline Male & 101 & 93.50 \\
Female & 7 & 6.50 \\
\hline Total & 108 & 100 \\
\hline Religion: & & \\
Christian & 88 & 81.50 \\
\hline Islam & 19 & 17.60 \\
Traditional worship & 1 & 0.90 \\
Total & 108 & 100 \\
\hline Educational Qualification: & & \\
\hline Second Degree & 44 & 40.70 \\
First Degree & 38 & 35.20 \\
Higher National Diploma & 23 & 21.30 \\
\hline O\&A Level & 3 & 2.80 \\
Total & 108 & 100 \\
\hline Designation: & & \\
\hline Project Manager & 4 & 3.70 \\
\hline Surveyor/Quantity Surveyor 3 & 39 & 36.10 \\
Architect & 14 & 13.00 \\
\hline Engineer & 46 & 42.60 \\
\hline Contractor/Subcontractor & 1 & 0.90 \\
\hline Artisans & 3 & 2.80 \\
\hline Others & 1 & 0.90 \\
\hline Total 1 & 108 & 100 \\
\hline Source: & & \\
\hline
\end{tabular}

Source: Field of study

In determining the team composition as shown in Table 4.2, it could be observed that 36(33.3\%) respondents normally worked in a team size of about $1-5$ members, $59(54.6 \%)$ worked in team size from $6-10,7(6.5 \%)$ worked in team size from $11-15,3(2.8 \%)$ worked in team size from $16-$ 20 and $3(2.8 \%)$ also worked in a team size above 20 .

Table 4.1.Distribution of Respondents in the Study Area 


\begin{tabular}{lll}
\hline Gender: & Frequency & Percent \\
\hline Male & 101 & 93.50 \\
Female & 7 & 6.50 \\
Total & 108 & 100 \\
Religion: & & \\
Christian & 88 & 81.50 \\
Islam & 19 & 17.60 \\
Traditional worship & 1 & 0.90 \\
Total & 108 & 100 \\
Educational Qualification: & & \\
Second Degree & 44 & 40.70 \\
First Degree & 38 & 35.20 \\
Higher National Diploma & 23 & 21.30 \\
\hline O\&A Level & 3 & 2.80 \\
Total & 108 & 100 \\
\hline Designation: & & \\
Project Manager & 4 & 3.70 \\
Surveyor/Quantity Surveyor 3 & 39 & 36.10 \\
Architect & 14 & 13.00 \\
\hline Engineer & 46 & 42.60 \\
\hline Contractor/Subcontractor & 1 & 0.90 \\
\hline Artisans & 3 & 2.80 \\
\hline Others & 1 & 0.90 \\
\hline Total 1 & 108 & 100 \\
\hline
\end{tabular}

Source: Field of study

It could be observed in Table 4.3 that $19(17.6 \%)$ respondents worked with only males, $2(1.9 \%)$ worked with only females, and $87(80.6 \%)$ respondents worked with both males and females.

Table 4.3.Team Composition by Gender

\begin{tabular}{lll}
\hline Gender & Frequency & Percentage \\
\hline Men Only & 19 & 17.60 \\
Female Only & 2 & 1.90 \\
Men and Women & 87 & 80.60 \\
Total & 108 & 100 \\
\hline
\end{tabular}

Source: Field of study

Most of the respondents showed in Table 4.4 suggest that, 106(98.1\%) were made up of different tribes whereas $2(1.9 \%)$ were of the same tribe.

Table 4.4.Team Composition by Tribe

\begin{tabular}{lll}
\hline Description & Frequency & Percentage \\
\hline Same tribe & 2 & 1.90 \\
Different tribe & 106 & 98.10 \\
Total & 108 & 100 \\
\hline
\end{tabular}

Source: Field of study 
Also, Table 4.5 suggested the majority of the respondents 83(76.9) answered that their team was normally made up of only Ghanaians whereas $25(23.1 \%)$ teams had both Ghanaian and other people from different countries.

Table 4.5.Team Composition by Nationality

\begin{tabular}{lll}
\hline Nationality & Frequency & Percentage \\
\hline Only Ghanaians & 83 & 76.90 \\
Mixed nationals & 25 & 23.10 \\
Total & 108 & 100 \\
\hline
\end{tabular}

Source: Field of study

In exploring the effects of team diversity on team effectiveness and output in the study area, It is observed from Table 4.6 that 14(13\%) strongly agree that they explore diversity, whiles $94(87 \%)$ also agreed that they explore team diversity. The table again shows that $1(9 \%)$ strongly agreed that they find it difficult taking instruction from the opposite gender, $7(6.5 \%)$ agreed that they find it difficult taking instructions from their female counterparts, $9(8.3 \%)$ respondents were uncertain, 55(50.9\%) disagreed to the assertion of difficulties in taking instruction from the opposite gender and finally $36(33.3 \%)$ strongly disagreed that they find it difficult taking instruction from the opposite gender. From the table, row four sorted to find out if respondents had any difficulty in taking instructions from someone younger than themselves. The responses are as follows; $6(5.6 \%)$ strongly agreed, 6(5.6) agreed, 16(14.8\%) neutral, 41(38\%) disagreed, and $39(36.1 \%)$ strongly disagreed. Row five also required respondents to give their opinions on whether they found it difficult taking instructions from someone of a different tribe. Their responses are $1(0.9 \%)$ strongly agreed, $5(4.6 \%)$ agreed, $2(1.9 \%)$ neutral, $43(39.8 \%)$ disagreed and $57(52.8 \%)$ strongly disagreed. The sixth row also gives out the responses that "because of the gender difference, it affects the output of the team: $2(1.9 \%)$ strongly agreed, $2(1.9 \%)$ agreed, $11(10.2 \%)$ neutral, $44(40.7 \%)$ disagreed, $49(45.4 \%)$ strongly disagreed. Row seven also sorted to find out whether the difference in the tribe had any negative influence on the final project of construction works: $1(0.9 \%)$ strongly agreed, 5(4.6\%) agreed, $13(12 \%)$ neutral, 39(36.1\%) disagreed, and 50(46.3\%) strongly disagreed. The eighth row sought to know whether the difference in educational background have effect on task completion; $1(0.9 \%)$ strongly agreed, $14(13 \%)$ agreed, $18(16.7 \%)$ neutral, $44(40.7 \%)$ disagreed, and 31(28.7) strongly disagreed. The ninth row sorted from the respondent if the gender differences affect team goal: $1(0.9 \%)$ strongly agreed, 4(3.7\%) agreed, 9(8.3\%) neutral, 51(47.2\%) disagreed, and 43(39.8\%) agreed. The tenth row was also sorted from respondents using the Likert scale to find out if the difference in religion affects the team's goal: 6(5.6\%) agreed, 10(9.3\%) neutral, 56(51.9\%) disagreed, 36(33.3\%) strongly disagreed. It was further revealed in Table 4.6 that $6(5.6 \%)$ of the respondents agreed that the difference in culture negatively affects output, 21(19.4\%) were neutral, 52(48.1\%) disagreed, and $29(26.9 \%)$ strongly disagreed. 
Table 4.6.Team Diversity and Team Effectiveness

\begin{tabular}{|c|c|c|c|c|c|c|c|c|c|c|c|}
\hline \multirow{2}{*}{$\begin{array}{c}\text { Does Team } \\
\text { Diversity } \\
\text { affect Team } \\
\text { Effectiveness } \\
\& \\
\text { Output? }\end{array}$} & \multicolumn{2}{|c|}{$\begin{array}{l}\text { Strongly } \\
\text { Agree }\end{array}$} & \multicolumn{2}{|c|}{ Agree } & \multicolumn{2}{|c|}{ Neutral } & \multicolumn{2}{|c|}{ Disagree } & \multicolumn{2}{|c|}{$\begin{array}{l}\text { Strongly } \\
\text { Disagree }\end{array}$} & \multirow[t]{2}{*}{$\begin{array}{c}\text { Interpretation } \\
\text { on }\end{array}$} \\
\hline & $F$ & $\%$ & $F$ & $\%$ & $F$ & $\%$ & $F$ & $\%$ & F & $\%$ & \\
\hline $\begin{array}{l}\text { My team } \\
\text { usually } \\
\text { explores } \\
\text { diversity }\end{array}$ & 14 & 13 & 98 & 87 & 0 & 0 & 0 & 0 & 0 & 0 & $\begin{array}{l}\text { Strength } \\
\text { outweigh } \\
\text { weakness } \\
\text { (agreed) }\end{array}$ \\
\hline $\begin{array}{l}\text { I find it } \\
\text { difficult } \\
\text { taking } \\
\text { instructions } \\
\text { from the } \\
\text { opposite } \\
\text { gender }\end{array}$ & 1 & 0.9 & 7 & 6.5 & 9 & 8.3 & 55 & 50.9 & 36 & 33.3 & $\begin{array}{l}\text { Weakness } \\
\text { outweigh } \\
\text { strength, } \\
\text { though both } \\
\text { exist } \\
\text { (disagreed) }\end{array}$ \\
\hline $\begin{array}{l}\text { I find it } \\
\text { difficult } \\
\text { taking } \\
\text { instructions } \\
\text { from } \\
\text { someone, } \\
\text { who is } \\
\text { younger than } \\
\text { me }\end{array}$ & 6 & 5.6 & 6 & 5.6 & 16 & 14.8 & 41 & 38 & 39 & 36.1 & $\begin{array}{l}\text { Weakness } \\
\text { outweigh } \\
\text { strength, } \\
\text { though both } \\
\text { exist } \\
\text { (disagreed) }\end{array}$ \\
\hline $\begin{array}{l}\text { It is difficult } \\
\text { for me to } \\
\text { take } \\
\text { instructions } \\
\text { from } \\
\text { someone of a } \\
\text { different } \\
\text { tribe }\end{array}$ & 1 & 0.9 & 5 & 4.6 & 2 & 1.9 & 43 & 39.8 & 57 & 52.8 & $\begin{array}{l}\text { Major } \\
\text { weakness } \\
\text { (disagree) }\end{array}$ \\
\hline $\begin{array}{l}\text { Because of } \\
\text { the } \\
\text { difference in } \\
\text { gender, it } \\
\text { affect the } \\
\text { output of the } \\
\text { team }\end{array}$ & 2 & 1.9 & 2 & 1.9 & 11 & 10.2 & 44 & 40.7 & 49 & 45.4 & $\begin{array}{l}\text { Weakness } \\
\text { outweigh } \\
\text { strength, } \\
\text { though both } \\
\text { exist } \\
\text { (disagreed) }\end{array}$ \\
\hline $\begin{array}{l}\text { The } \\
\text { differences } \\
\text { in tribe, }\end{array}$ & 1 & 0.9 & 5 & 4.6 & 13 & 12.0 & 39 & 36.1 & 50 & 46.3 & $\begin{array}{l}\text { Weakness } \\
\text { outweigh } \\
\text { strength, } \\
\text { though both }\end{array}$ \\
\hline
\end{tabular}




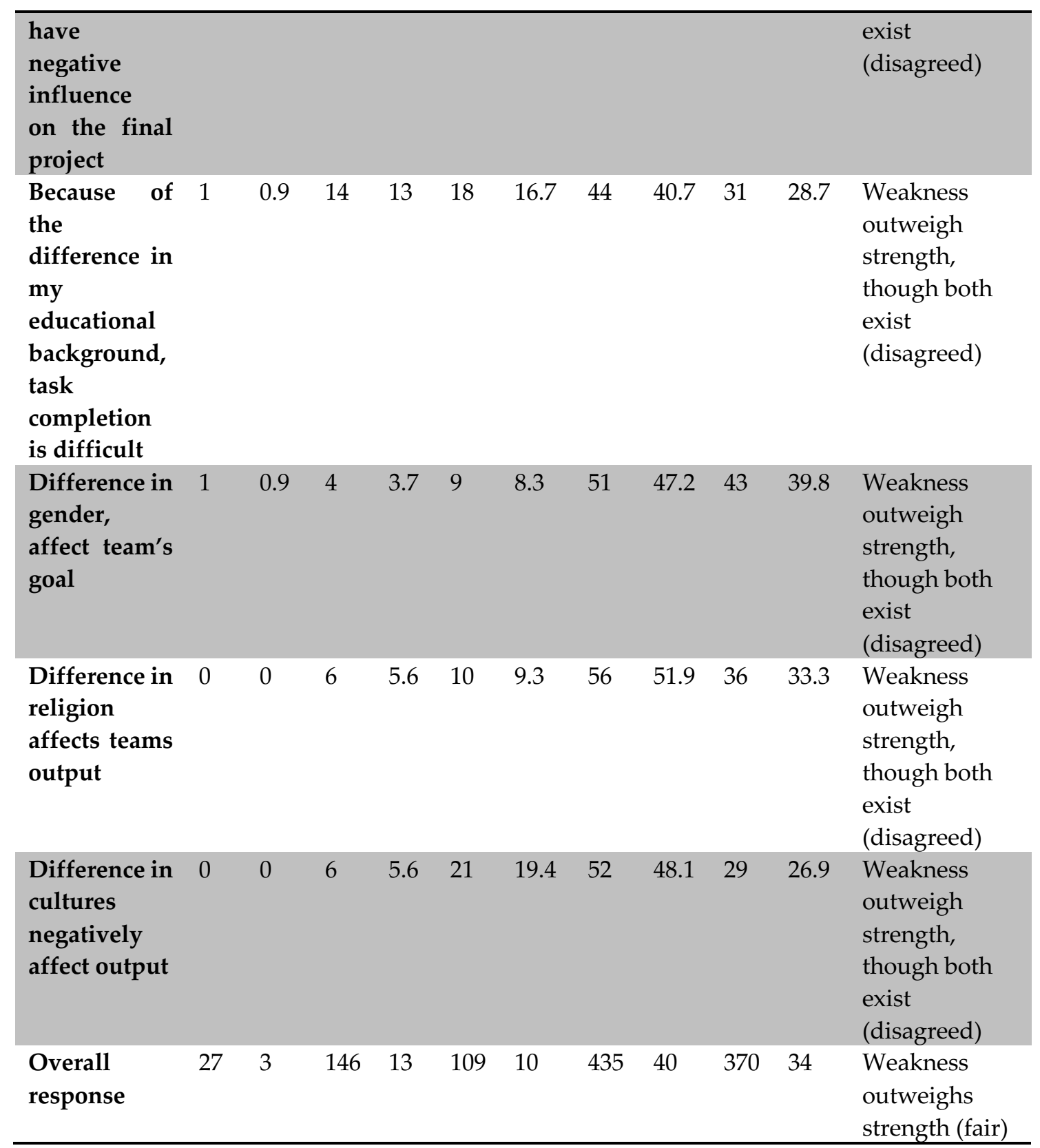

F = Frequency; \% = Percent; Source: Field survey

From table 4.7: row 2, asked respondents whether the difference in age cause conflict in the construction industry. 10(9.3\%) respondents strongly agreed with the statement. 37(34.3\%) agreed, 22(20.4) were not certain, 32(29.6\%) disagreed, and 7(6.5\%) strongly disagreed.

Table 4.7: row 3, asked respondents whether the difference in gender cause conflict in the construction industry. $3(2.8 \%)$ respondents strongly agreed to the statement, $28(25.9 \%)$ agreed, 20(18.5\%) neutral, 51(47.2\%) strongly disagreed and 6(5.5\%) disagreed. Table 4.7: row 4, asked respondents whether differences in religion cause conflict. 2(1.9\%) respondents strongly agreed, 24(22.2\%) agreed, 19(17.6\%) neutral, 52(48.1) disagreed, 11(10.2) strongly disagreed. Table 4.7: row 5 asked respondents whether differences in educational background cause conflict. 13(12\%) strongly agree, 50(46.3\%) agree, 20(18.5\%) neutral, 2(21.3\%) disagree and 2(1.9) strongly disagreed. Table 4.7: row 6 asked respondents whether the difference in culture can cause conflict. 
2(19\%) respondent strongly agreed, 29(26.9\%) agreed, 34(31.5\%) neutral, 35(32.4\%) disagreed, $8(7.4 \%)$ strongly disagreed.

Table 4.7.Team Diversity and Conflicts

\begin{tabular}{|c|c|c|c|c|c|c|c|c|c|c|c|}
\hline \multirow{2}{*}{$\begin{array}{l}\text { Conflict in } \\
\text { teams } \\
\text { comes about } \\
\text { as a } \\
\text { result of: }\end{array}$} & \multicolumn{2}{|c|}{$\begin{array}{l}\text { Strongly } \\
\text { Agree }\end{array}$} & \multicolumn{2}{|c|}{ Agree } & \multicolumn{2}{|c|}{ Neutral } & \multicolumn{2}{|c|}{ Disagree } & \multicolumn{2}{|c|}{$\begin{array}{l}\text { Strongly } \\
\text { Disagree }\end{array}$} & \multirow[t]{2}{*}{$\begin{array}{c}\text { Interpretation } \\
\text { On }\end{array}$} \\
\hline & $\bar{F}$ & $\%$ & $F$ & $\%$ & $\bar{F}$ & $\%$ & $\bar{F}$ & $\%$ & $F$ & $\%$ & \\
\hline $\begin{array}{l}\text { Differences in } \\
\text { age }\end{array}$ & 10 & 9.3 & 37 & 34.3 & 22 & 20.4 & 32 & 29.6 & 7 & 6.5 & $\begin{array}{l}\text { Not in } \\
\text { position to } \\
\text { be judged }\end{array}$ \\
\hline $\begin{array}{l}\text { Difference in } \\
\text { gender }\end{array}$ & 3 & 2.8 & 28 & 25.9 & 20 & 18.5 & 51 & 47.2 & 6 & 5.5 & $\begin{array}{l}\text { Weakness } \\
\text { outweigh } \\
\text { strength(disa } \\
\text { gree) }\end{array}$ \\
\hline $\begin{array}{l}\text { Difference in } \\
\text { religion }\end{array}$ & 2 & 1.9 & 24 & 22.2 & 19 & 17.6 & 52 & 48.1 & 11 & 10.2 & $\begin{array}{l}\text { Weakness } \\
\text { outweigh } \\
\text { strength } \\
\text { (disagree) }\end{array}$ \\
\hline $\begin{array}{l}\text { Difference in } \\
\text { educational } \\
\text { background }\end{array}$ & 13 & 12 & 50 & 46.3 & 20 & 18.5 & 23 & 21.3 & 2 & 1.9 & $\begin{array}{l}\text { Strength } \\
\text { outweigh } \\
\text { weakness } \\
\text { (agrees) }\end{array}$ \\
\hline $\begin{array}{l}\text { Difference in } \\
\text { cultures }\end{array}$ & 2 & 1.9 & 29 & 26.9 & 34 & 31.5 & 35 & 32.4 & 8 & 7.4 & $\begin{array}{l}\text { Not in } \\
\text { position to } \\
\text { be judged }\end{array}$ \\
\hline $\begin{array}{l}\text { Difference in } \\
\text { tribe }\end{array}$ & 6 & 5.6 & 26 & 24.1 & 30 & 27.8 & 28 & 25.9 & 18 & 16.7 & $\begin{array}{l}\text { Weakness } \\
\text { outweigh } \\
\text { strength(disa } \\
\text { gree) }\end{array}$ \\
\hline $\begin{array}{l}\text { Overall } \\
\text { response }\end{array}$ & 36 & 6 & 194 & 30 & 145 & 22 & 221 & 34 & 52 & 8 & $\begin{array}{l}\text { Weakness } \\
\text { outweigh } \\
\text { strength }\end{array}$ \\
\hline
\end{tabular}

F = Frequency; \% = Percent; Source: Field survey

Table 4.8: row 7 asked respondents whether differences in the tribe can cause conflict. $6(5.6 \%)$ respondent strongly agreed, 26(24.1\%) agreed, 30(27.8\%) neutral, 28(25.9\%) disagreed, 18(16.7\%) strongly disagreed.

Table 4.8, depicts the outcome of unresolved conflict on a diverse team. Likert scale was again used to assess the effects of unresolved conflict on team effectiveness and individual performance in the team. Table $4.867(62 \%)$ strongly agreed that unresolved conflict will affect team effectiveness. The table also clearly depicts that $50(46.3 \%)$ agreed that unresolved conflict can have negative effects on individual performance. 
Table 4.8.Effects of Conflicts on Team Diversity

\begin{tabular}{|c|c|c|c|c|c|c|c|c|c|c|}
\hline \multirow{2}{*}{$\begin{array}{c}\text { When } \\
\text { conflicts are } \\
\text { not resolved } \\
\text { in the team: }\end{array}$} & \multicolumn{2}{|c|}{$\begin{array}{c}\text { Strongly } \\
\text { Agree }\end{array}$} & \multicolumn{2}{|c|}{ Agree } & \multicolumn{2}{|c|}{ Neutral } & \multicolumn{2}{|c|}{ Disagree } & \multicolumn{2}{|c|}{$\begin{array}{l}\text { Strongly } \\
\text { Disagree }\end{array}$} \\
\hline & $\bar{F}$ & $\%$ & $\mathbf{F}$ & $\%$ & $\mathbf{F}$ & $\%$ & $\bar{F}$ & $\%$ & $\mathbf{F}$ & $\%$ \\
\hline $\begin{array}{l}\text { Team } \\
\text { effectiveness } \\
\text { is affected }\end{array}$ & 67 & 62 & 27 & 25 & 7 & 6.5 & 7 & 6.5 & 0 & 0 \\
\hline $\begin{array}{l}\text { Individual } \\
\text { performance } \\
\text { in the team is } \\
\text { affected }\end{array}$ & 40 & 37 & 50 & 46.3 & 6 & 5.6 & 12 & 11.1 & 0 & 0 \\
\hline
\end{tabular}

Table 4.9 shows responses on how the individual and team members as a variable enhance team effectiveness. It is observed that $60(55.6 \%)$ respondents agreed that individual input influences overall project output, and also $77(71.3 \%)$ respondents agreed that team members demonstrated a good sense of expertise during the team work. The majority of respondents $80(74.1 \%)$ agreed that the project team successfully achieved the project objectives.

Table 4.9.Individual and Team members' Contribution to Team Effectiveness

\begin{tabular}{|c|c|c|c|c|c|c|c|c|c|c|}
\hline \multirow{2}{*}{$\begin{array}{l}\text { When } \\
\text { conflicts are } \\
\text { not resolved } \\
\text { in the team: }\end{array}$} & \multicolumn{2}{|c|}{$\begin{array}{l}\text { Strongly } \\
\text { Agree }\end{array}$} & \multicolumn{2}{|c|}{ Agree } & \multicolumn{2}{|c|}{ Neutral } & \multicolumn{2}{|c|}{ Disagree } & \multicolumn{2}{|c|}{$\begin{array}{l}\text { Strongly } \\
\text { Disagree }\end{array}$} \\
\hline & $\mathbf{F}$ & $\%$ & F & $\%$ & $\mathbf{F}$ & $\%$ & F & $\%$ & $\mathbf{F}$ & $\%$ \\
\hline $\begin{array}{l}\text { Individual input } \\
\text { have influence on } \\
\text { the overall } \\
\text { project } \\
\text { output }\end{array}$ & 43 & 39.8 & 60 & 55.6 & 3 & 2.8 & 2 & 1.9 & 1 & 0.9 \\
\hline $\begin{array}{l}\text { Project } \\
\text { completed } \\
\text { met the quality } \\
\text { standard } \\
\text { specified } \\
\text { by the client }\end{array}$ & 19 & 17.6 & 80 & 74.1 & 8 & 7.4 & 1 & 0.9 & 0 & 0 \\
\hline
\end{tabular}




\begin{tabular}{lllllllllll}
\hline $\begin{array}{l}\text { Team members } \\
\text { demonstrated a } \\
\text { good }\end{array}$ & 13 & 12.0 & 77 & 71.3 & 17 & 15. & 1 & 0.9 & 0 & 0 \\
sense of expertise & & & & & & & & & & \\
\hline
\end{tabular}

F = Frequency; \% = Percent; Source: Field survey

Table 4.10 , depicts that $68(63 \%)$ respondents which represent the majority agreed that, the team leader demonstrated good service, $77(71.3 \%)$ respondents agreed that the team leader demonstrated a good technical ability on a project, $72(66.7 \%)$ of the respondent also agreed that the team leader made sure that professionals and skilled people were hired during the implementation of the project, $75(69.4 \%)$ of the respondents also agreed that the project leaders' contribution enables the team to be effective.

Table 4.10.Team Leader Contribution to Team Effectiveness

\begin{tabular}{|c|c|c|c|c|c|c|c|c|c|c|}
\hline \multirow{2}{*}{$\begin{array}{c}\text { Team Leader's } \\
\text { Contribution to } \\
\text { Team } \\
\text { Effectiveness: }\end{array}$} & \multicolumn{2}{|c|}{$\begin{array}{l}\text { Strongly } \\
\text { Agree }\end{array}$} & \multicolumn{2}{|c|}{ Agree } & \multicolumn{2}{|c|}{ Neutral } & \multicolumn{2}{|c|}{ Disagree } & \multicolumn{2}{|c|}{$\begin{array}{l}\text { Strongly } \\
\text { Disagree }\end{array}$} \\
\hline & F & $\%$ & F & $\%$ & $\mathbf{F}$ & $\%$ & $\mathbf{F}$ & $\%$ & $\mathbf{F}$ & $\%$ \\
\hline $\begin{array}{l}\text { Good service of the } \\
\text { team leader is } \\
\text { demonstrated } \\
\text { during a project }\end{array}$ & 21 & 19.4 & 68 & 63 & 18 & 16.7 & 1 & 0.9 & 0 & 0 \\
\hline $\begin{array}{l}\text { The team leader } \\
\text { demonstrates } \\
\text { good technical } \\
\text { ability on a project }\end{array}$ & 19 & 17.6 & 77 & 71.3 & 11 & 10.2 & 1 & 0.9 & 0 & 0 \\
\hline $\begin{array}{l}\text { Team leader makes } \\
\text { sure that } \\
\text { professional and } \\
\text { skilled people } \\
\text { are hired for a } \\
\text { project }\end{array}$ & 17 & 15.7 & 72 & 66.7 & 10 & 9.3 & 9 & 8.3 & 0 & 0 \\
\hline $\begin{array}{l}\text { Project leader's } \\
\text { contributions } \\
\text { enables the team to } \\
\text { be effective }\end{array}$ & 15 & 13.9 & 75 & 69.4 & 18 & 16.7 & 0 & 0 & 0 & 0 \\
\hline
\end{tabular}

F = Frequency; \% = Percent; Source: Field survey 
Table 4.11 reveals that $86(79.6 \%)$ the respondents agreed that team members render a decent service throughout project execution. Also, the majority of respondents $52(48 \%)$ agreed that the required equipment and tools needed for the project were available and it enhanced output, also the majority of the respondents $59(54.6 \%)$ agreed that, members of the team communicated well among themselves. Also in Table 4.11,90(83.3\%) of the respondents agreed that the client was satisfied with the quality of project executed.

Table 4.11.Team Working Processes' Contribution to Team Effectiveness

\begin{tabular}{|c|c|c|c|c|c|c|c|c|c|c|}
\hline \multirow{2}{*}{$\begin{array}{l}\text { Team Working } \\
\text { Processes' } \\
\text { Contribution } \\
\text { to Team } \\
\text { Effectiveness }\end{array}$} & \multicolumn{2}{|c|}{$\begin{array}{c}\text { Strongly } \\
\text { Agree }\end{array}$} & \multicolumn{2}{|c|}{ Agree } & \multicolumn{2}{|c|}{ Neutral } & \multicolumn{2}{|c|}{ Disagree } & \multicolumn{2}{|c|}{$\begin{array}{l}\text { Strongly } \\
\text { Disagree }\end{array}$} \\
\hline & $\mathbf{F}$ & $\%$ & $\mathbf{F}$ & $\%$ & $\mathbf{F}$ & $\%$ & $\mathbf{F}$ & $\%$ & $F$ & $\%$ \\
\hline $\begin{array}{l}\text { Good service } \\
\text { among team } \\
\text { members during } \\
\text { project } \\
\text { implementation }\end{array}$ & 11 & 10.2 & 86 & 79.6 & 8 & 7.4 & 3 & 2.8 & 0 & 0 \\
\hline $\begin{array}{l}\text { The required } \\
\text { equipment } \\
\text { and tools need for } \\
\text { the } \\
\text { project was } \\
\text { available and it } \\
\text { enhance output }\end{array}$ & 10 & 9.3 & 52 & 48.1 & 20 & $\begin{array}{c}18 . \\
5\end{array}$ & 26 & 24.1 & 0 & 0 \\
\hline $\begin{array}{l}\text { Members of a team } \\
\text { communicate } \\
\text { among } \\
\text { themselves well }\end{array}$ & 25 & 23.1 & 59 & 54.6 & 21 & $\begin{array}{c}19 . \\
4\end{array}$ & 3 & 2.8 & 0 & 0 \\
\hline $\begin{array}{l}\text { Project completed } \\
\text { met the } \\
\text { quality standard } \\
\text { specified } \\
\text { by the client }\end{array}$ & 10 & 9.3 & 90 & 83.3 & 6 & 5.6 & 2 & 1.9 & 0 & 0 \\
\hline
\end{tabular}

F = Frequency; \% = Percent; Source: Field survey

Table 4.12 indicates the contributions of organizations toward team effectiveness. The table depicts that $32(29.6 \%)$ strongly agreed that an increase in wages positively affects team members contribution to work well, $42(38.9 \%)$ agreed that wages affect team members, $27(25 \%)$ were neutral, $5(4.6 \%)$ disagreed and $2(1.9 \%)$ strongly disagreed that wages affect the contribution of team members agreed, $1(0.9 \%)$ strongly disagree and $5(4.6 \%)$ respondents were neutral on the assertion that being treated fairly by employers motivates workers to work well. 
The second row of table 4.12, sorted to find if team members are motivated to work well when treated fairly by employers. It revealed that $40(37 \%)$ strongly agreed $62(57.4 \%)$ agreed, $1(0.9 \%)$ strongly disagree and 5(4.6\%) respondents were neutral on the assertion that being treated fairly by employers motivates workers to work well. From table 4.12, it is observed majority $42(38.9 \%)$ respondent agreed that increase in wages positively affect an individual's contribution to work well. It implies that wage as a motivation enables people to put in their best. However, the second row depicts that most people $62(57.4 \%)$ are more motivated to work well when treated fairly by their employers.

Table 4.12.Organization's Contribution to Team Effectiveness

\begin{tabular}{|c|c|c|c|c|c|c|c|c|c|c|}
\hline \multirow{2}{*}{$\begin{array}{c}\text { Organization } \\
\text { contribution to } \\
\text { Team } \\
\text { Effectiveness }\end{array}$} & \multicolumn{2}{|c|}{$\begin{array}{c}\text { Strongly } \\
\text { Agree }\end{array}$} & \multicolumn{2}{|c|}{ Agree } & \multicolumn{2}{|c|}{ Neutral } & \multicolumn{2}{|c|}{ Disagree } & \multicolumn{2}{|c|}{$\begin{array}{l}\text { Strongly } \\
\text { Disagree }\end{array}$} \\
\hline & $F$ & $\%$ & $F$ & $\%$ & $F$ & $\%$ & $F$ & $\%$ & F & $\%$ \\
\hline $\begin{array}{l}\text { Increase in wages } \\
\text { positively affect } \\
\text { my } \\
\text { contribution to } \\
\text { work well }\end{array}$ & 32 & 29.6 & 42 & 38.9 & 27 & 25 & 5 & 4.6 & 2 & 1.9 \\
\hline $\begin{array}{l}\text { I am motivated to } \\
\text { work } \\
\text { well when treated } \\
\text { fairly by } \\
\text { my employer }\end{array}$ & 40 & 37 & 62 & 57.4 & 5 & 4.6 & 0 & 0 & 1 & 0.9 \\
\hline
\end{tabular}

F = Frequency; \% = Percent; Source: Field survey

In terms of responses given by interviewees to illustrate the effect of team diversity on team effectiveness, some of the insightful responses were:

"In-fact diversity enhances team effectiveness, especially when there is collaboration. One professional cannot do the work. We need an architect, a surveyor, an engineer, and all those who matter to help realize the project goal in the construction field. Also, especially, the few women who are normally part of the team enrich the team with their knowledge" (Architect).

"In the construction team, the gender differences, age, ethnicity does have any impact on project............".(Project manager)

".........as professionals we place much emphasis on executing the work at hand and not dwelling on individual differences". (Architect and Surveyor).

"All that we need is the wages, so just give us work and pay us after we are done. We don't care if you are a woman, from the north, south, east, or the west". (Laborers) 
Conflict is an inevitable aspect of teamwork and can be both beneficial and detrimental to teamwork. When asked if diversity in age, gender, religion, educational background, culture, and tribe cause conflict. Respondents gave different opinions from various angles. One of the artisans noted that:

"The religion or sex of the project leader is not so important to us, we just want to work and receive our wages after we have completed our schedule"

In contrast, some respondents said conflicts arise as a result of differences in gender and age. Another artisan asserted that:

"I prefer to take instructions from a man than a woman. Women are supposed to rather follow the instructions of men and not the other way round. Why should I obey someone younger than me".

Similarly, some respondents were of the view that:

"Conflict arises when insults are traded between tribes or among people of different tribes. Also, the difference in the educational background can result in conflict. For instance, imagine that I have been on the job for several years, with my maximum work experience I can perform better than the so-called graduates. So do you expect me to follow the wrong instructions? Never, I won't do that. Those graduates when they get out of school, they presume they know everything...................".

\section{Discussion and Conclusion}

The study identified the forms of team diversity according to size, gender, tribe, and nationality. Gender, and Tribe diversity as revealed in tables 4.3 and 4.4adds credence to the fact that team diversity is significantly explored in the study area, bringing all sides together to work in the spirit of meeting the specified goals. Diversity in terms of nationality has not been strong in the study area. This could be due to a high level of preference given to nationals with the requisite expertise than non-nationals who price themselves expensively in the construction industry. Tables $4.3,4.4$, and 4.5 affirm the claim that team diversity is significantly explored in the construction industry in the Ashanti region.

Table 4.6 clearly shows that over 80 percent of the respondents agreed that they neither find it difficult to take instruction from the opposite gender nor do they find it difficult to take instruction from someone of a different tribe. Over 70 percent also confirmed that they do not find difficult taking instructions from someone, who is younger than them. It was confirmed in the study that team effectiveness and output is not necessarily influenced by the diversity in tribe, gender, educational background, and culture as over 80 percent of the respondents held this assertion. The totality, weakness of agreement outweighs strength and respondents generally disagree that surface-level diversity affects effectiveness. This supportsJehn and Benzkorora's (2004) meta-analysis that diversity in demographic and social-economic featuresbecome less significant and key on team performance and output as group members work together inspecific contexts over some time.

The general responses of the agreement offset strength and respondents disagreed with the assertion that, generally diversity in the surface-level generates conflict. This goes to buttress the opinions held by Silvestre (2008) that there is no substantial outcome between diversity and conflict. There was also no relationship between diversity in tribe and conflict. Further findings in Table 4.8 confirmed William and O'Reilly's (1998) assertion that diversity can affect the satisfaction and commitment of member and group processes.

Factors identified to be essential in influencing team effectiveness were individual and team members' contributions, team leaders and working processes, and the organization's 
contribution. The findings affirm the Klimoski and Jones(1995) model of team effectiveness, which emphasis that team effectiveness does not emerge from only individual effort, the instead interpersonal dynamic of the team, and the level of compatibility between team members. Also, Tannenbaum et al. (1992) observed that team with better individual task proficiency; abilities, and skills will perform better. So the finding which depicts a $60 \%$ agreeing to the fact that individual input influences overall project output led to the realization of the team achieving its objectives. Employees are more motivated to work well when treated fairly by their employers. This implies that the construction team members normally get motivated with recognition and respect from their employers.

It can be concluded from the findings that, team diversity which is so much explored in the study area has not had any negative effect on team effectiveness in the construction industry. However, the issue of team diversity remains very sensitive in the construction industry and calls for regular assessment to ensure a harmonious working environment for all stakeholders. This will instill confidence among stakeholders and improve the growth prospects of the construction industry in the Kumasi metropolitan of Ashanti region and beyond.

\section{Reference}

Bahl, M. (2018), Inclusion and diversity: By the numbers, available at: https://www.cognizant.com/futureofwork/whitepaper/making-room-reflections-ondiversity-inclusion-in-the-future-of-work (accessed 15 August 2020).

Byrne, D.E. (1971). The attraction paradigm, New York, Academic Press.

Eisenhardt, K.M. and Graebner, M.E. (2007). “Theory building from cases: Opportunities and challenges", .Academy of Management Journal, 50(1), 25-32.

Easterby-Smith, M., Thorpe, R. and Jackson, P. (2008). Management Research: An Introduction (3rd $E d)$, London, Sage.

Gadzekpo, A.A. (2007). Improving the Quality of Polytechnic Education in Ghana through SelfEvaluation of Course: The Case study of Kumasi Polytechnic (Unpublished Master's Thesis). University of Twente, Enschede, Netherlands.

Inegbedion, H., Sunday, E., Asaleye, A., Lawal, A. and Adebanji, A. (2020). “Managing Diversity for Organizational Efficiency", Sage Open, 1-10.

Jehn, K.A. and Bezrukova, K. (2004). "A Field Study of Group Diversity, Workgroup Context, and Performance", Journal of Organizational Behavior, 25(6), 703-729.

Kaur, N. and Arora, P. (2020). "Acknowledge gender diversity and inclusion as key to organizational growth: a review and trends", Journal of Critical Reviews, 7(6), 125-131.

Klimoski, R. and Jones, R. (1995). Staffing for effective group decision making: Key issues in matching people and teams, San Francisco, Jossey-Bass Publishers.

Miles, M. and Huberman, M. (1994). Qualitative Data Analysis, Thousand Oaks, Sage.

Odita, A.O. and Egbule, S. (2015), Workforce diversity and organizationaleffectiveness in Nigerian brewery industry, available at: https://pdfs.semanticscholar.org/3ef1/934b3bb5a83862bbeb51c161d5b96bb0d94b.pdf (accessed 18 September 2018).

Offerman, L.R. and Gowing, M.K. (1990). “Organizations of the future: Changes and challenges", American Psychologist, 45(2), 95-108. 
Tajfel, H. and Turner, J.C. (1986). The social identity theory of intergroup behavior. In S.Worchel, and W.Austin (Eds), Social psychology of intergroup relations (2nd ed.), Chicago, Nelson Hall.

Tannenbaum, S., Beard, R. and Slas, E. (1992). Teambuilding and its influence on team effectiveness: An examination of conceptual and empirical development, New York, Elsevier.

Tenas, S. (2012), The importance and benefits of diversity, available at:https://www.teenink.com/opinion/environment/article/465407/The-Importance-andBenefits-of-Diversity/ (accessed 15 November 2018).

Thomas, D.A. and Ely, R. (1996). "Making differences matter a new paradigm in managing diversity", Harvard Business Review, 74(5), 79-90.

Tsui, A.S. and Gutek, B.A. (1999). Demographic differences in organizations: Current research and future directions, Lanham, Lexington Books/Macmillan.

Tuuli, M.M., Baiden, B.K. and Badu, E. (2007). "Assessment and Enforcement of Liquidated Damages in Construction Contract in Ghana", Structural Survey, 25(314), 204-219.

Urbancova, H., Hudakova, M. and Fajeikova, A. (2020). “Diversity management as a tool of sustainability of competitive advantage", Sustainability, 12(12), 1-16.

Willaims, K.Y. and O'Reilly, C.A (1998). Demography and diversity in organization: a review of 40 years of research, In B. M. Staw, \& L. L. Cummings (Eds.), Research in organizational behavior, Greenwich, JAI Press.

World Bank (2003). “Ghana 2003 Country Assessment Report Washington, D.C. Ghana Country Department", The World Bank.

World Bank, World Development Indicators. (2003). Ghana 2003 assessment report [Data file]. Retrieved from https://documents.worldbank.org/curated/en/2003/06/3583079/ghanacountry-procurement-assessment-report-vol-5-5annex-9-labor

Yaprak, A. (2002). "Globalization: strategies to build a great global firm in the new economy", Thunderbird International Business Review, 44(2), 297.

Yin, R.K. (2003). Case study research: Design and methods (3rd Ed.), Thousand Oaks, Sage. 